ERRATUM

https://doi.org/10.15746/sms.17.002.e1

\title{
Erratum: The Structure and Orientation of Governance for Healthy Cities Programs
}

\section{Won Gi Jhang}

Department of Preventive Medicine, Soonchunhyang University College of Medicine, Cheonan, Korea

https://doi.org/10.15746/sms.17.002

Soonchunhyang Med Sci. 2017;23(1):8-14

There was an error in the article, "The structure and orientation of governance for Healthy Cities programs." The footnote at the bottom of page 8 should be corrected as follows. We apologize for any inconvenience that it may have caused.

\section{Corrected Version of Footnote}

*이 논문은 2015년 보건복지부 연구보고서 “건강도시 교육과정 개발 및 적용방안 연구(A study on the development and application of Healthy Cities curriculum, 박윤형 외)"에 수록된 본 논문 저자의 글(47-56쪽)에 기초하였다. 